\title{
Modulation of ICAM-1 expression in human alveolar macrophages in vitro
}

\author{
M. Fattal-German, F. Le Roy Ladurie, J. Cerrina, F. Lecerf, S. Berrih-Aknin
}

\begin{abstract}
Modulation of ICAM-1 expression in human alveolar macrophages in vitro. M. FattalGerman, F. Le Roy Ladurie, J. Cerrina, F. Lecerf, S. Berrih-Aknin. @ ERS Journals Ltd 1996.

ABSTRACT: Modulation of intercellular adhesion molecule-1 (ICAM-1) expression may be a basic mechanism by which alveolar macrophages (AMs) regulate the inflammatory process in the lung in response to local stimuli.

As a model for studying the anti-inflammatory activity of drugs on human AMs, we investigated the effects of fusafungine, an antibiotic for local use by aerosol with anti-inflammatory properties, and that of the glucocorticoid dexamethasone, on ICAM-1 expression induced in vitro by recombinant interferon- $\gamma($ IFN- $\gamma)$. ICAM-1 protein expression was studied on AMs by means of flow cytometry with an antiCD54 monoclonal antibody; messenger ribonucleic acid (mRNA) levels were determined by reverse transcriptase-polymerase chain reaction (RT-PCR).

ICAM-1 was expressed before culture on $21 \%$ of bronchoalveolar lavage (BAL) cells, with low intensity. Culture for $24 \mathrm{~h}$ with rIFN- $\gamma$ resulted in a significant increase in ICAM-1 protein expression ( $82 \%$ of cells were strongly positive). Fusafungine significantly inhibited rIFN- $\gamma$-induced ICAM-1-protein expression on AMs in a concentration-dependent fashion. The mechanism of ICAM-1 downregulation was mainly post-transcriptional, but also partly transcriptional. By contrast, dexamethasone did not influence rIFN- $\gamma$-induced ICAM-1 expression.

This in vitro model using human AMs should prove useful for investigating the cellular and molecular targets of anti-inflammatory drugs.
\end{abstract} Eur Respir J., 1996, 9, 463-471.

Laboratoire d'Immunologie CNRS URA 1159 and Department of Thoracic and Vascular Surgery and Heart-Lung Transplantation, Université Paris-XI, Hôpital MarieLannelongue, Le Plessis-Robinson, France.

Correspondence: M. Fattal-German Laboratoire d'Immunologie CNRS URA 1159

Université de Paris-XI

Hôpital Marie-Lannelongue

92350 - Le Plessis-Robinson

France

Keywords: Alveolar macrophages anti-inflammatory drugs

intercellular adhesion molecule-1

Received: May 181995

Accepted after revision November 271995

This work was supported by grants from AFLM, Université Paris-Sud and IRIS.
Macrophages are resident tissue cells that play a major role in natural and acquired immunity. Alveolar macrophages (AMs), in addition to many other important functions, participate in the modulation of immune responses as antigen-presenting cells (APCs). They thus possess surface molecules that enable them to recognize and adhere to lymphocytes. In addition to presentation of antigen to the T-cell receptor, several antigen-nonspecific accessory molecules promote attachment of T-cells to APC; this is an important step in the induction of the immune response, through the transmission of regulatory signals to the T-cell, and the induction of target cell functional activity [1].

Intercellular adhesion molecules (ICAMs) on the APC surface, together with leucocyte function-associated molecule-1 (LFA-1) on T-cells, form a critical adhesive ligand-receptor pair. Interaction of LFA-1 and ICAMs is required to activate resting $\mathrm{T}$-cells, and to induce activated T-cells to proliferate and function optimally. The ICAM class currently contains three molecules. The complementary deoxyribonucleic acids (cDNAs) for the three ICAMs have been cloned and the corresponding amino acid sequences have been determined [2-4]. There is a high degree of sequence homology between the extracellular portions (e.g. $48 \%$ between ICAM-3 and ICAM-1 [5]). However, these molecules differ in their tissue distribution, binding activity for LFA-1, and the functions of the intracytoplasmic region. ICAM-1 has been reported to bind LFA-1 with an avidity several times greater than the other ICAMs [6]. The main functional role of ICAM-1 and ICAM-2 is merely to bind to LFA-1, the only molecule transducing signals that enhance cell activation. Only ICAM-3 has two clear functions, as it binds the LFA-1 molecule and is also able to transduce signals. Interestingly, ICAM-1 (CD54) is expressed weakly on normal resting AMs. However, it can be induced on monocytes/macrophages in culture following activation with inflammatory mediators, including lipo-polysaccharide (LPS), 12-O-tetradecanoyl phorbol13-acetate (TPA), interleukin-1 (IL-1), interleukin-3 (IL3), interleukin-4 (IL-4), recombinant human granulocyte/ macrophage colony-stimulating factor (GM-CSF), tumour necrosis factor- $\alpha$ (TNF- $\alpha)$ and recombinant gamma-interferon $(\mathrm{rIFN}-\gamma)$ [7-12].

Regulation of ICAM-1 expression may be one of the basic mechanisms by which AMs modulate immune and inflammatory processes in the lung in response to local stimuli, through interactions between AMs and T-cells [13]. As a model to study the anti-inflammatory activity of drugs on AMs, we investigated the effects of fusafungine, an antibiotic for local use by aerosol with anti-inflammatory properties [14-17], and that of the glucocorticoid, 
dexamethasone, on rIFN- $\gamma$-induced ICAM-1 expression in cultured human AMs. Expression was studied in terms of the surface antigen (immunocytofluorimetry) and the messenger ribonucleic acid (mRNA) (reverse transcriptase-polymerase chain reaction (RT-PCR)).

\section{Materials and methods}

\section{Reagents}

AMs were cultured in RPMI 1640 medium (Gibco-BRL) containing $2 \mathrm{mM}$ L-glutamine, $25 \mathrm{mM}$ hydroxyethylpiperazine ethanesulphonic acid (HEPES) (Gibco-BRL), $100 \mathrm{U} \cdot \mathrm{mL}^{-1}$ penicillin $\mathrm{G}, 100 \mu \mathrm{g} \cdot \mathrm{mL}^{-1}$ streptomycin, 5 $\mu \mathrm{g} \cdot \mathrm{mL}^{-1}$ fungizone, $50 \mu \mathrm{g} \cdot \mathrm{mL}^{-1}$ amikacin, and $10 \%$ human $\mathrm{AB}$ serum.

rIFN- $\gamma$ was a gift from Roussel-Uclaf (Paris). Stock rIFN- $\gamma$ was prepared at $1 \times 10^{6} \mathrm{U} \cdot \mathrm{mL}^{-1}$ in sterile supplemented RPMI-1640.

Fusafungine (IRIS, France) was solubilized in dimethyl sulphoxide (DMSO) at $10 \mathrm{mg} \cdot \mathrm{mL}^{-1}$, and twofold dilutions were made in supplemented RPMI medium with vigorous shaking to obtain solutions ranging from 320 to $10 \mu \mathrm{g} \cdot \mathrm{mL}^{-1}$, i.e. 20 times the final concentrations in the assay.

Dexamethasone (Sigma) was stored as a stock solution of $5 \times 10^{-3} \mathrm{M}$ in ethanol at $-20^{\circ} \mathrm{C}$.

\section{Bronchoalveolar lavage (BAL)}

BAL for diagnosis or routine monitoring was performed in the subsegmental bronchus of the middle lobe of patients treated at Hôpital Marie-Lannelongue for lung diseases. With the patient's informed consent, three 50 $\mathrm{mL}$ aliquots of sterile $0.9 \%$ saline were instilled, aspirated manually and pooled. Samples remaining after cytological, bacteriological and virological tests were used in this study. Samples were kept on ice, and then filtered through a single layer of cotton gauze. Total and differential cell counts were performed. Cell viability always exceeded $85 \%$ (trypan blue exclusion). BAL samples containing bacteria (direct examination) or more than $50 \%$ neutrophils were discarded.

\section{Macrophage culture}

BAL fluid was centrifuged at $300 \times \mathrm{g}$ for $10 \mathrm{~min}$ at $4^{\circ} \mathrm{C}$, and cells were resuspended in supplemented RPMI. AMs were adherence purified, and then $1 \times 10^{6}$ AMs were incubated at $37^{\circ} \mathrm{C}$ with $5 \% \mathrm{CO}_{2}$ in 24-well plates with rIFN$\gamma\left(250 \mathrm{U} \cdot \mathrm{mL}^{-1}\right)$. The effects of rIFN- $\gamma$ and that of the drugs on AM activation measured by ICAM-1 expression were investigated after $24 \mathrm{~h}$ of incubation. For this, nonadherent cells were discarded and, after gentle washing with medium, adherent AMs were detached from the plates using cold phosphate-buffered saline (PBS) containing $0.02 \%$ ethylenediamine tetra-acetic acid (EDTA) and vigorous pipetting.

\section{Flow cytometric phenotype analysis}

ICAM-1 expression on the surface of AMs was investigated before and after culture, by means of flow cytometry with indirect immunofluorescence [18]. The specific monoclonal antibodies (MoAbs) used were as follows: IOT2a (mouse-immunoglobulin $\mathrm{G}_{2 \alpha}\left(\mathrm{IgG}_{2 \alpha}\right)$, conjugated with fluorescein isothiocyanate (FITC); Immunotech), which binds a common nonpolymorphic human leucocyte antigen-DR (HLA-DR) epitope; and IOL54 (unconjugated mouse- $\operatorname{IgG}_{1}$; Immunotech), that reacts with the ICAM-1 antigen (CD54). Fluorescence data were collected in a gate of 5,000 cells selected according to size and granularity, using a fluorescence-activated cell sorter (FACScan) apparatus (Becton Dickinson) with an argon laser operating at $488 \mathrm{~nm}$. In this gate, the proportion of HLA-DR-positive cells ranged 75-98\% (mean (SD) 87 (9)\%). Data were analysed using Lysis-2 software (Becton Dickinson). Fluorescence associated with anti-CD54 MoAbs on activated cells clearly showed two peaks, one corresponding to weakly positive cells and the second to strongly positive cells. ICAM-1 fluorescence is expressed as the percentage of strongly positive cells (fluorescence intensity $>30$ on the logarithmic scale). Mean fluorescence intensity (mFI) was also used as an index of ICAM-1 density on the cell surface. Percentage inhibition was calculated as follows: (\% CD54+ cells after culture without fusafungine - \% CD54+ cells after culture with fusafungine $) \times 100 /(\%$ CD54+ cells after culture without fusafungine - \% CD54+ cells before culture).

\section{ICAM-1 mRNA detection}

ICAM-1 mRNA was assayed by means of polymerase chain reaction (PCR) on complementary deoxyribonucleic acid (cDNA) derived enzymatically from ribonucleic acid (RNA) extracted from $1 \times 10^{6}$ fresh or cultured BAL cells. Cells were pelleted by centrifugation and resuspended in $400 \mu \mathrm{L}$ of RNAzol (Bioprobe, Paris), which lyses cells and protects RNA from degradation, and were kept at $-80^{\circ} \mathrm{C}$ until RNA extraction.

Total RNA extraction. Total RNA was extracted from AMs by a guanidinium thiocyanate-phenol-chloroform method [19].

Primers. All primers were synthesized by Genset (Paris). For ICAM-1 PCR a pair of 20 nucleotide primers, located in the 150-348 nucleotide sequence of the I domain of ICAM-1 cDNA, were chosen to amplify a 189 base pair (bp) fragment. This sequence has no homology with NCAM-1 cDNA, and very little homology with ICAM-2 or ICAM-3 cDNAs. The primer sequences were 5' AAA GTC ATC CTG CCC CGG GG 3' (sense) and 5' AGG GCA GTT TGA ATA GCA CA 3' (antisense). The latter was used for specific reverse transcription. The fusion temperatures were 66 and $62^{\circ} \mathrm{C}$, respectively.

To check for the presence of cDNA in all the negative samples and for semiquantitative assay of ICAM-1 mRNA, glyceraldehyde-3-phosphate dehydrogenase (GAPDH) mRNA was investigated in parallel, using the 
following primers: 5' ATC ACC ATC TTC CAG GAG CG 3' (sense), and 5' CCT GCT TCA CCA CCT TCT TG 3' (antisense). This latter primer was used for specific reverse transcription of mRNA into GAPDH cDNA. This pair of 20 nucleotide primers amplifies a $573 \mathrm{bp}$ fragment.

Specific reverse transcription. To convert mRNA into cDNA for PCR, total RNA (1 $\mu \mathrm{g})$ was first heated to $72^{\circ} \mathrm{C}$ for $10 \mathrm{~min}$ and cooled on ice. The mRNA was then reverse transcribed in a $50 \mu \mathrm{L}$ reaction volume containing buffer (Gibco-BRL), $10 \mathrm{mM}$ dithiothreitol, $20 \mathrm{U}$ of ribonulease (RNase) inhibitor (RNAsin, Boehringer), $0.5 \mathrm{mM}$ (each) deoxynucleotide triphosphate (dNTP) (Bioprobe) mix, $40 \mu \mathrm{M}$ specific primer, and $50 \mathrm{U}$ of Molony murine leukaemia virus (MMLV) reverse transcriptase (Gibco-BRL), for $1 \mathrm{~h}$ at $37^{\circ} \mathrm{C}$ in a water bath. The enzyme was then denatured by incubation at $95^{\circ} \mathrm{C}$ for $5 \mathrm{~min}$.

PCR for cDNA amplification. cDNA $(5 \mu \mathrm{L})$ was amplified in a $50 \mu \mathrm{L}$ reaction containing buffer $(20 \mathrm{mM}$ Tris$\mathrm{HCl}, \mathrm{pH} 8.55,16 \mathrm{mM}\left(\mathrm{NH}_{4}\right) 2 \mathrm{SO}_{4}, 150 \mu \mathrm{g} \cdot \mathrm{mL}^{-1}$ bovine serum albumin (BSA), $1.25 \mathrm{mM} \mathrm{MgCl}_{2}$ ) containing 0.2 $\mathrm{mM}$ each dNTP, $0.5 \mu \mathrm{M}$ each primer, and $1.25 \mathrm{U}$ of TAQ DNA-polymerase (Eurobio, Les Ulis, France). The samples were amplified in a thermocycler (PHC-3, Techne) with the following parameters: $94^{\circ} \mathrm{C}, 1 \mathrm{~min} ; 63^{\circ} \mathrm{C}, 1$ $\min ; 72^{\circ} \mathrm{C}, 1 \mathrm{~min} ; 40$ cycles). A final extension step was performed at $72^{\circ} \mathrm{C}$ for $1.5 \mathrm{~min}$. Positive and negative controls were analysed in all experiments. mRNA extracts not submitted to reverse transcription were also included to check the absence of contaminating DNA. All samples were analysed at least three times. GAPDH mRNA was assessed in the same conditions.

Analysis of PCR products. PCR products $(10 \mu \mathrm{L})$ were analysed by electrophoresis on $2 \%$ agarose gel containing $0.5 \mu \mathrm{g} \cdot \mathrm{mL}^{-1}$ ethidium bromide. The bp size marker was the pUC 18 Hae III digest (Sigma). Gels were photographed under ultra violet (UV) light. For semiquantitative assessment of band intensity, the gels were photographed with

a) Before culture

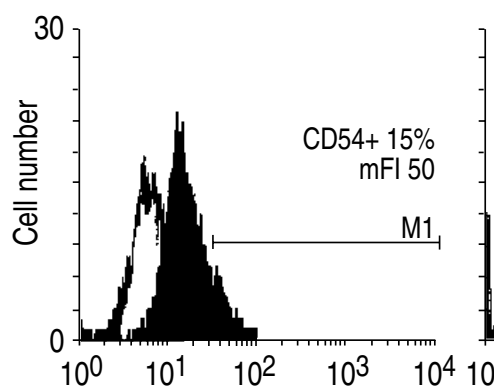

b) $0 \mu \mathrm{g}$ fusafungine

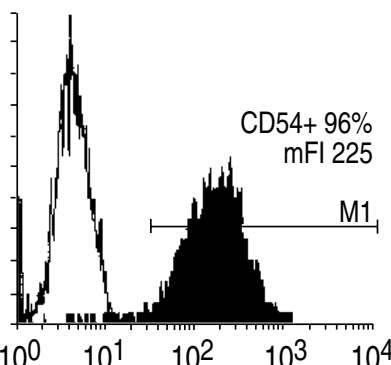

a video imager (Imstar, Paris) in reverse mode, stained DNA appearing as black bands. The relative amount of DNA was determined densitometrically by using Starwise Akigel software (Imstar, Paris). Results for each sample are expressed as arbitrary optical density (OD) units related to the integrated volume calculated on the densitometer.

\section{Statistical analysis}

Comparisons were made using Student's two-sided ttest. Linear regression analysis was used to identify correlations. Differences with p-values lower than 0.05 were considered significant.

\section{Results}

A total of 14 BAL samples were studied. Of these, two samples were excluded because AMs were highly activated, as more than $70 \%$ of AMs (74 and 77\%, respectively) expressed the ICAM-1 antigen before culture, although at a low level. Cell counts ranged 95-30\% (mean $74 \pm 21 \%$ ), $35-2 \%$ (mean $10 \pm 10 \%$ ) and $60-1 \%$ (mean $16 \pm 19 \%$ ) for AMs, neutrophils and lymphocytes, respectively.

\section{Basal ICAM-1 expression on alveolar macrophages}

The ICAM-1 molecule was expressed on 5-42\% of gated cells (mean (SD) 21(13)\%). ICAM-1 antigen density on the cell surface expressed as the $\mathrm{mFI}$ ranged 35-137 (overall mean (SD) of mFIs 66.7 (29.3)).

\section{Fusafungine inhibits rIFN - induced ICAM-1 protein expression on $A M s$ in vitro}

Cells from 10 BAL specimens were incubated for $24 \mathrm{~h}$ with rIFN- $\gamma\left(250 \mathrm{U} \cdot \mathrm{mL}^{-1}\right)$ and various concentrations of fusafungine $\left(0.5-16 \mu \mathrm{g} \cdot \mathrm{mL}^{-1}\right)$. Cell viability always exceeded $85 \%$ (trypan blue exclusion) and cell size was unaffected by fusafungine. Flow cytometry showed that $\begin{array}{ll}\text { c) } 2 \mu \mathrm{g} \text { fusafungine } & \text { d) } 8 \mu \mathrm{g} \text { fusafungine }\end{array}$

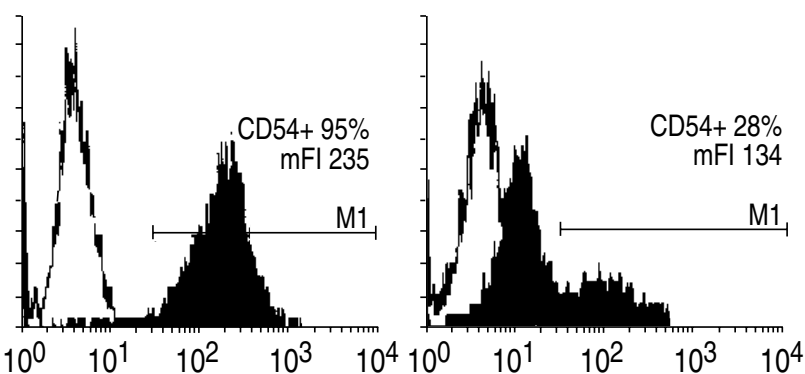

Fluorescence intensity

Fig. 1. - Effect of fusafungine on ICAM-1 protein expression by alveolar macrophages stimulated by rIFN- $\gamma$ from one representative BAL sample. Flow cytometric analysis of ICAM-1-specific immunofluorescence with an anti-CD54 MoAb (right histogram) compared with control fluorescence (left histogram). Results are expressed as the percentage of CD54-positive cells and the mean fluorescence intensity: a) before culture; b) after $24 \mathrm{~h}$ of culture with $250 \mu \cdot \mathrm{mL}^{-1} \mathrm{rIFN}-\gamma$; c) after $24 \mathrm{~h}$ of culture with $250 \mathrm{U} \cdot \mathrm{mL}^{-1} \mathrm{rIFN}-\gamma$ and $2 \mu \mathrm{g} \cdot \mathrm{mL}^{-1}$ of fusafungine; d) after $24 \mathrm{~h}$ of culture with $250 \mathrm{U} \cdot \mathrm{mL}^{-1} \mathrm{rIFN}-\gamma$ and $8 \mu \mathrm{g} \cdot \mathrm{mL}^{-1}$ of fusafungine. ICAM-1: intercellular adhesion molecule-1; BAL: bronchoalveolar lavage; MoAb: monoclonal antibody; rIFN- $\gamma$ : recombinant interferon- $\gamma$; mFI: mean fluorescence intensity. 
ICAM-1 expression on AMs was markedly increased after $24 \mathrm{~h}$ of culture with $\mathrm{rIFN}-\gamma$, since it was observed on $82 \pm 16 \%$ of cells $(\mathrm{p}<0.001$ vs values before culture), with a high intensity $(\mathrm{mFI}=172.6 \pm 74.5 ; \mathrm{p}<0.001 \mathrm{vs}$ values before culture). ICAM-1 was expressed on $87-100 \%$ of HLA-DR-positive cells. The percentage of ICAM-1positive cells fell in a fusafungine concentration-dependent fashion (fig. 1). Fusafungine inhibition of ICAM-1 expression on BAL cells (see Materials and Methods) was detectable at $2 \mu \mathrm{g} \cdot \mathrm{mL}^{-1}$ (mean \% inhibition 28 (SD 32)\% inhibition; $\mathrm{p}<0.005$ vs $0 \mu \mathrm{g} \cdot \mathrm{mL}^{-1}$ fusafungine), and

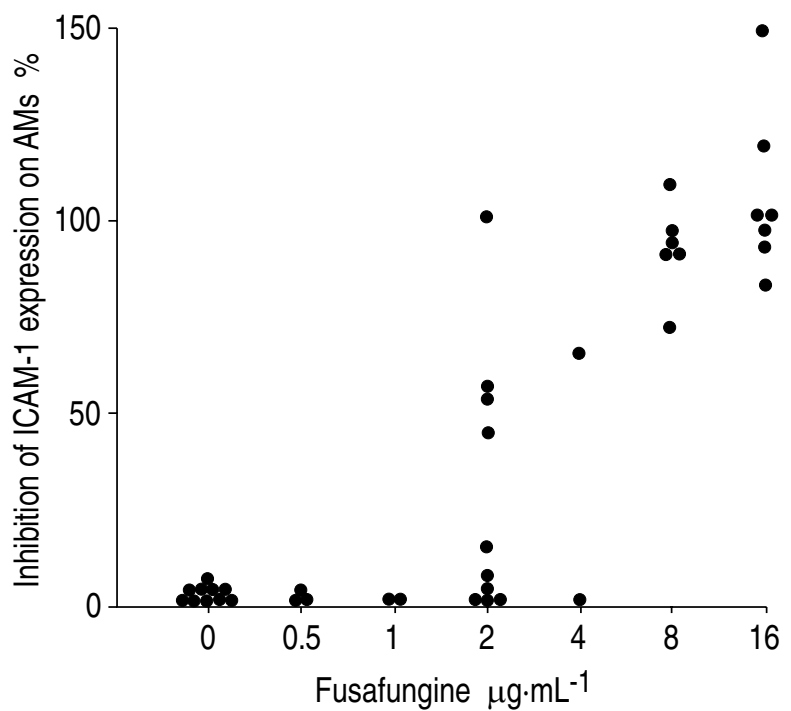

Fig. 2. - Inhibitory effect of fusafungine on ICAM-1 protein expression by alveolar macrophages from 10 BAL samples after $24 \mathrm{~h}$ of culture with $250 \mathrm{U} \cdot \mathrm{mL}^{-1} \mathrm{rIFN}-\gamma$. Each point represents one determination, all $10 \mathrm{BAL}$ were tested at $0 \mu \mathrm{g} \cdot \mathrm{mL}^{-1}$. For abbreviations see legend to figure 1 . increased with concentration (fig. 2). Of note, because of the small number of AMs available due to the poor volume of BAL remaining after clinical investigations, every drug concentration could not be tested on all 10 BAL. Thus, in figure 2, all $10 \mathrm{BAL}$ were tested only for the control without drug. The mean inhibition was $92 \%$ (sD 11) at $8 \mu \mathrm{g} \cdot \mathrm{mL}^{-1}\left(\mathrm{p}<0.001\right.$ vs $\left.0 \mu \mathrm{g} \cdot \mathrm{mL}^{-1}\right)$ and inhibition was total at $16 \mu \mathrm{g} \cdot \mathrm{mL}^{-1}(\mathrm{p}<0.001)$. As illustrated in figure 1 , fusafungine also reduced the $\mathrm{mFI}$ in parallel to the percentage of positive cells.

It is noteworthy that AMs from BAL samples Nos 7 and 8 were inhibited by more than $100 \%$ ( 133 and $120 \%$ inhibition, respectively) by $16 \mu \mathrm{g} \cdot \mathrm{mL}^{-1}$ fusafungine. Indeed, ICAM-1 was expressed by a large proportion of these AMs before culture (40 and $42 \%$, respectively) (table 1) but at a low intensity ( $\mathrm{mFI}=44$ and 35 , respectively); after $24 \mathrm{~h}$ culture with rIFN- $\gamma$ and $16 \mu \mathrm{g} \cdot \mathrm{mL}^{-1}$ of fusafungine, values were lower than before culture (29 and 19\%, respectively).

ICAM-1 protein expression induced by culture with rIFN- $\gamma$ was, thus, blocked by fusafungine, which also appeared to further downregulate basal ICAM-1 expression on activated AMs.

\section{Fusafungine inhibits rIFN- $\gamma$-induced ICAM-1 mRNA expression in $A M s$ in vitro}

To determine whether fusafungine modulates the induction of ICAM-1 expression at the transcriptional or post-transcriptional level, ICAM-1 mRNA was tested for in AMs from 6 BAL samples before and after $24 \mathrm{~h}$ of culture, by applying PCR to ICAM-1 cDNA obtained after reverse transcription of mRNA. As shown in table 1, ICAM-1 mRNA transcripts were present before cul-

Table 1. - Effect of fusafungine on the expression of ICAM-1 antigen and mRNA in AMs from BAL $(n=6)$

\begin{tabular}{|c|c|c|c|c|c|c|}
\hline \multirow{2}{*}{$\begin{array}{l}\text { BAL } \\
\text { No. }\end{array}$} & \multirow{2}{*}{$\begin{array}{l}\text { ICAM-1 } \\
\text { expression }\end{array}$} & \multirow{2}{*}{$\begin{array}{l}\text { Before } \\
\text { culture }\end{array}$} & \multicolumn{4}{|c|}{ After $24 \mathrm{~h}$ culture with fusafungine $\mu \mathrm{g} \cdot \mathrm{mL}^{-1}$} \\
\hline & & & 0 & 2 & 8 & 16 \\
\hline 5 & $\begin{array}{l}\text { CD54+ cells \% } \\
\text { mFI } \\
\text { ICAM-1 mRNA* }\end{array}$ & $\begin{array}{c}5 \\
56 \\
0.10\end{array}$ & $\begin{array}{c}39 \\
350 \\
0.3\end{array}$ & $\begin{array}{c}37 \\
360 \\
0.11\end{array}$ & $\begin{array}{c}7 \\
162 \\
0.10\end{array}$ & $\begin{array}{l}\text { ND } \\
\text { ND } \\
\text { ND }\end{array}$ \\
\hline 6 & $\begin{array}{l}\text { CD54+ cells \% } \\
\text { mFI } \\
\text { ICAM-1 mRNA* }\end{array}$ & $\begin{array}{c}22 \\
81 \\
0.21\end{array}$ & $\begin{array}{c}85 \\
195 \\
0.92\end{array}$ & $\begin{array}{c}75 \\
182 \\
0.31\end{array}$ & $\begin{array}{c}27 \\
160 \\
0.23\end{array}$ & $\begin{array}{l}\text { ND } \\
\text { ND } \\
\text { ND }\end{array}$ \\
\hline 7 & $\begin{array}{l}\text { CD54+ cells } \% \\
\text { mFI } \\
\text { ICAM-1 mRNA* }\end{array}$ & $\begin{array}{c}40 \\
44 \\
0.21\end{array}$ & $\begin{array}{c}100 \\
88 \\
0.69\end{array}$ & $\begin{array}{c}68 \\
59 \\
0.54\end{array}$ & $\begin{array}{l}\text { ND } \\
\text { ND } \\
\text { ND }\end{array}$ & $\begin{array}{c}29 \\
39 \\
0.24\end{array}$ \\
\hline 8 & $\begin{array}{l}\text { CD54+ cells \% } \\
\text { mFI } \\
\text { ICAM-1 mRNA* }\end{array}$ & $\begin{array}{c}42 \\
35 \\
0.37\end{array}$ & $\begin{array}{c}85 \\
89 \\
1.07\end{array}$ & $\begin{array}{c}40 \\
111 \\
1.08\end{array}$ & $\begin{array}{l}\text { ND } \\
\text { ND } \\
\text { ND }\end{array}$ & $\begin{array}{c}19 \\
84 \\
0.87\end{array}$ \\
\hline 9 & $\begin{array}{l}\text { CD54+ cells } \% \\
\text { mFI } \\
\text { ICAM-1 mRNA* }\end{array}$ & $\begin{array}{c}34 \\
43 \\
0\end{array}$ & $\begin{array}{c}94 \\
231 \\
0.29\end{array}$ & $\begin{array}{c}94 \\
235 \\
0.48\end{array}$ & $\begin{array}{c}28 \\
140 \\
0.37\end{array}$ & $\begin{array}{c}39 \\
146 \\
0.12\end{array}$ \\
\hline 10 & $\begin{array}{l}\text { CD54+ cells \% } \\
\text { mFI } \\
\text { ICAM-1 mRNA* }\end{array}$ & $\begin{array}{c}9 \\
42 \\
0.14\end{array}$ & $\begin{array}{c}73 \\
208 \\
0.72\end{array}$ & $\begin{array}{c}71 \\
235 \\
0.98\end{array}$ & $\begin{array}{l}\text { ND } \\
\text { ND } \\
\text { ND }\end{array}$ & $\begin{array}{l}10 \\
210 \\
0.16\end{array}$ \\
\hline
\end{tabular}

*: expressed as the intensity of optical density (OD) of the $189 \mathrm{bp}$ band on gels after electrophoresis of the PCR products. BAL: bronchoalveolar lavage; ICAM-1: intercellular adhesion molecule-1; mFI: mean fluorescence; mRNA: messenger ribonucleic acid; ND: not determined. 
ture in 5 of the 6 samples, but at a low level. The level of ICAM-1 mRNA was evaluated according to the optical density (OD) of the 189 bp band for each sample. AM culture with rIFN- $\gamma$ induced ICAM- 1 mRNA expression in every case $(\mathrm{p}<0.01$, OD before culture vs OD after $24 \mathrm{~h}$ of culture) and OD values correlated with $\mathrm{mFI}$ values $(\mathrm{r}=0.73 ; \mathrm{n}=6)$ but not with the percentage of CD54+ cells ( $r=0.37$ ). ICAM-1 mRNA synthesis was significantly inhibited by $8 \mu \mathrm{g} \cdot \mathrm{mL}^{-1}$ fusafungine $(\mathrm{p}<0.05$, $\mathrm{OD}$ at $8 \mu \mathrm{g} \cdot \mathrm{mL}^{-1} v s \mathrm{OD}$ at $\left.0 \mu \mathrm{g} \cdot \mathrm{mL}^{-1}\right)$. At $2 \mu \mathrm{g} \cdot \mathrm{mL}^{-1}$ fusafungine, ICAM-1 mRNA expression was inhibited in 3 of the 6 samples. Figure 3 illustrates typical results of ICAM-1 antigen analysis by means of immunocytofluorimetry and that of ICAM-1 mRNA using PCR, before culture and after $24 \mathrm{~h}$ of culture with rIFN- $\gamma$ and various concentrations of fusafungine. In this experiment, ICAM-1 mRNA transcription (expressed as OD) fell as the concentration of fusafungine increased. Surprisingly, GAPDH mRNA levels fell in parallel. However, whilst the ICAM-1 mRNA OD was four times lower with $16 \mu \mathrm{g} \cdot \mathrm{mL}^{-1}$ fusafungine than without fusafungine, the GAPDH mRNA OD only fell by 1.8 times.

Fusafungine, thus, significantly inhibited ICAM-1 mRNA expression. However, the inhibitory effect on ICAM-1 transcription was observed at higher concentrations than those inhibiting ICAM-1 antigen expression, suggesting that fusafungine acts mainly on post-transcription rather than transcription.

\section{Persistent effect of fusafungine on ICAM-1 expression}

Whether the inhibitory effect of fusafungine persisted after drug removal was then investigated, on one
BAL containing a sufficient number of AMs. After 24 $h$ of culture with rIFN- $\gamma$ and fusafungine, supernatants were removed and fresh supplemented RPMI medium containing no rIFN- $\gamma$ or fusafungine was added. After a further $24 \mathrm{~h}$ of incubation, AMs were analysed for ICAM-1 antigen and mRNA expression. Fusafungine inhibited ICAM-1 expression at both the post-transcriptional and transcriptional levels, in a concentration-dependent manner (fig. 4). After removal both of rIFN- $\gamma$ and fusafungine, the inhibitory effect previously observed at $16 \mu \mathrm{g} \cdot \mathrm{mL}^{-1}$ fusafungine on the percentage of ICAM-1positive cells and on mRNA synthesis persisted. However, antigen density was higher, probably owing to the time lag between mRNA transcription and translation. At a lower concentration of fusafungine $\left(2 \mu \mathrm{g} \cdot \mathrm{mL}^{-1}\right)$, the stimulatory effect of rIFN- $\gamma$ on ICAM- 1 expression persisted, but not the inhibitory effect of fusafungine.

These experiments indicated that fusafungine inhibited the rIFN- $\gamma$-induced expression both of ICAM-1 protein and mRNA. Moreover, the inhibitory effect observed with high doses of fusafugine persisted after removal both of the drug and the stimulator.

Comparative effects of fusafungine on spontaneous and rIFN- $\gamma$-induced ICAM-1 expression by AMs

The effects of fusafungine on basal and rIFN- $\gamma$-induced ICAM-1 expression by freshly isolated human AMs were then compared. Before culture, $20 \%$ of BAL cells were CD54-positive, with an mFI of 65 (fig. 5). Culture in the presence or absence of rIFN- $\gamma$ resulted in increased ICAM-1 antigen expression (88 and 86\% of CD54-positive cells, respectively) but at a low level in the absence

\begin{tabular}{|c|c|c|}
\hline time hr & 0 & 24 \\
\hline
\end{tabular}

\begin{tabular}{|l|l|llll|}
\hline Fusafungine $\mu \mathrm{g} \cdot \mathrm{mL}^{-1}$ & 0 & 0 & 2 & 8 & 16 \\
\hline
\end{tabular}

\begin{tabular}{|c|c|c|c|c|c|}
\hline $\begin{array}{c}\% \text { CD54 positive cells } \\
\text { mFI }\end{array}$ & $\begin{array}{l}34 \\
43\end{array}$ & $\begin{array}{l}94 \\
231\end{array}$ & $\begin{array}{l}94 \\
235\end{array}$ & $\begin{array}{l}28 \\
140\end{array}$ & $\begin{array}{l}39 \\
146\end{array}$ \\
\hline \multirow[t]{2}{*}{ ICAM-1 } & & $=$ & $=$ & $\infty$ & - \\
\hline & 0 & 0.29 & 0.48 & 0.37 & 0.12 \\
\hline
\end{tabular}

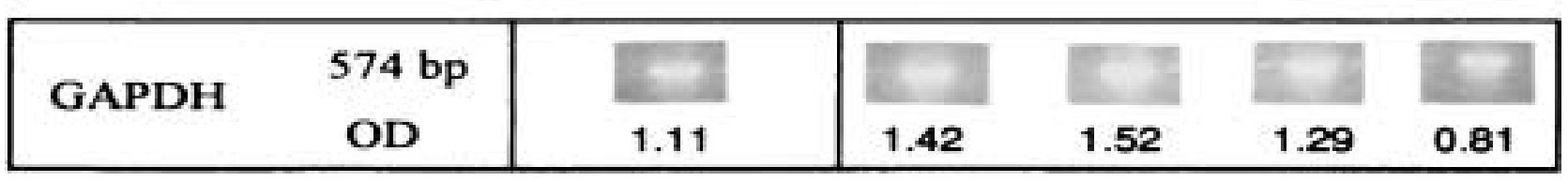

Fig. 3. - Effect of fusafungine on ICAM-1 expression by alveolar macrophages from one representative BAL sample after 24 hr culture with $250 \mathrm{U} \cdot \mathrm{mL}^{-1} \mathrm{rIFN}-\gamma$. ICAM-1 protein expression was determined by immunocytofluorimetric analysis using the CD54 MoAb. Results were recorded as the percentage of ICAM-1 positive cells and the mean fluorescence intensity. ICAM-1 mRNA was determined by PCR on cDNA obtained after specific reverse transcription. The PCR products were evaluated by densitometric analysis of the expected 189 bp-band on gel electrophoresis and the results expressed in arbitrary units of optical density (OD). GAPDH mRNA was determined in parallel as control. bp: base pairs; OD: optical density; GAPDH: glyceraldehyde-3-phosphate dehydrogenase. For further abbreviations see legend to figure 1. 


\begin{tabular}{|c|c|c|c|c|c|c|c|}
\hline & & \multicolumn{6}{|c|}{ New medium } \\
\hline & & \multicolumn{3}{|c|}{$\begin{array}{l}\text { IFN + } \\
\text { fusafungine }\end{array}$} & \multicolumn{3}{|c|}{$\begin{array}{l}\text { without IFN or } \\
\text { fusafungine }\end{array}$} \\
\hline time hr & 0 & & 24 & & & 48 & \\
\hline Fusafungine $\mu \mathrm{g} \cdot \mathrm{mL}^{-1}$ & 0 & 0 & 2 & 16 & 0 & 2 & 16 \\
\hline \multirow{2}{*}{$\begin{array}{c}\% \text { CD54 positive cells } \\
\mathrm{mFl}\end{array}$} & 11 & 83 & 50 & 31 & 84 & 83 & 30 \\
\hline & 52 & 80 & 69 & 92 & 195 & 150 & 162 \\
\hline \multirow{2}{*}{ ICAM-1 } & 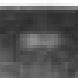 & +2 & $\sin$ & $\infty$ & 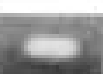 & 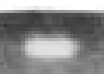 & 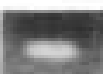 \\
\hline & 0 & 0.66 & 0.36 & 0.22 & 0.42 & 0.46 & 0.24 \\
\hline
\end{tabular}

Fig. 4. - Persistence of the inhibitory effect of fusafungine on rIFN- $\gamma$-induced ICAM-1 expression by alveolar macrophages from one representative BAL. AMs were cultured for $24 \mathrm{hr}$ with rIFN- $\gamma$ in the presence or absence of fusafungine; the medium was then replaced and cells were further incubated for $24 \mathrm{hr}$ without rIFN- $\gamma$ or fusafungine. Protein expression was determined by immunocytofluorimetric analysis using the CD54 MoAb. Results were recorded as the percentage of ICAM-1 positive cells and the mean fluorescence intensity. ICAM-1 mRNA was determined by PCR on cDNA obtained after specific reverse transcription. The PCR products were evaluated by densitometric analysis of the expected 189 bp-band on gel electrophoresis and the results expressed in arbitrary units of optical density (OD). For abbreviations see legends to figure 1 and 3.

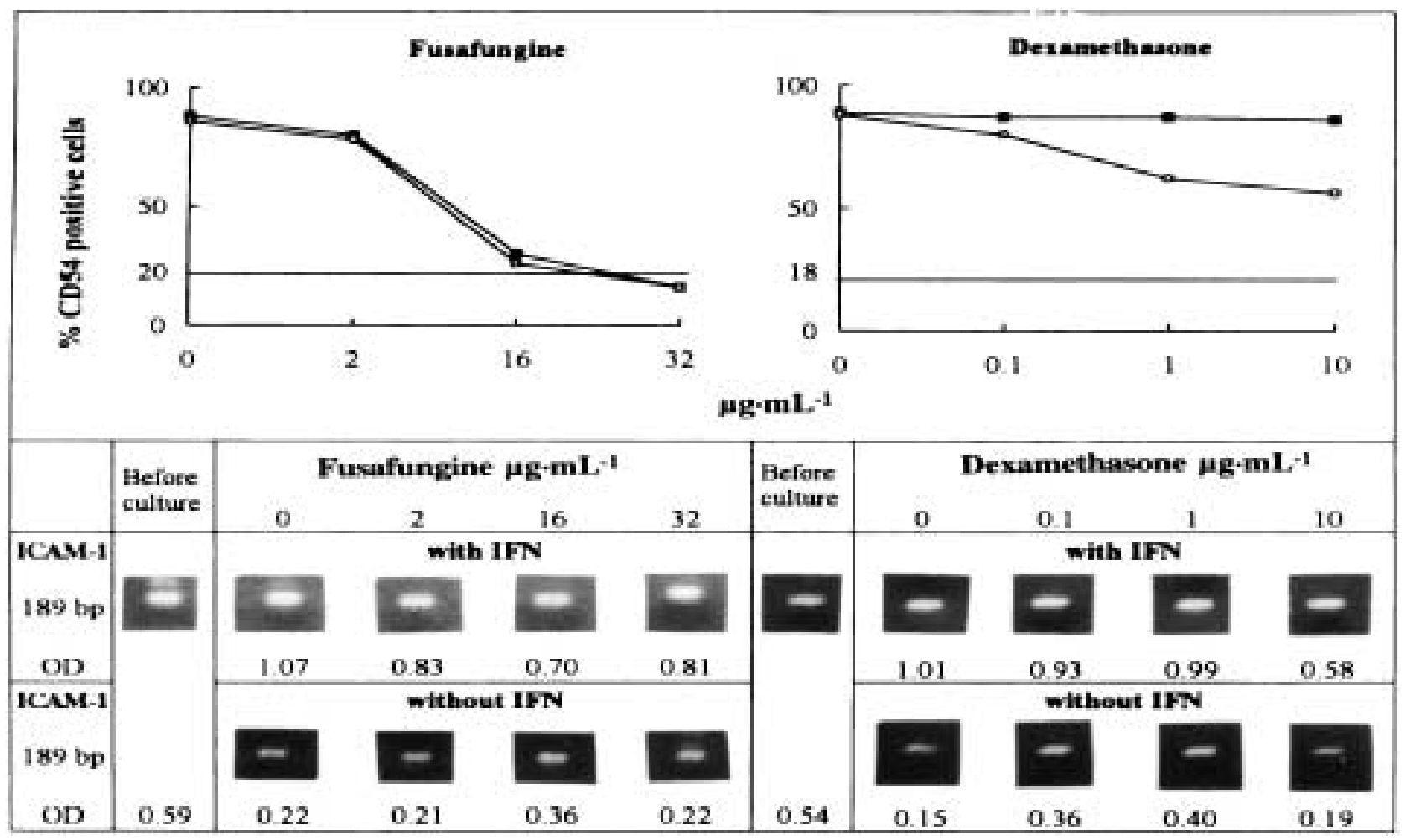

Fig. 5. - Comparative effects of fusafungine and dexamethasone on spontaneous and rIFN- $\gamma$-induced ICAM-1 expression by alveolar macrophages after $24 \mathrm{~h}$ culture. Upper panels: ICAM-1 protein expression was determined as the percentage of ICAM-1-positive cells in flow cytometry with anti-CD54 MoAb. Culture in the presence (- ) or absence (-O-) of $250 \mathrm{U} \cdot \mathrm{mL}^{-1} \mathrm{rIFN}-\gamma$. The horizontal line represents the percentage of CD54-positive cells before culture. Lower panel: ICAM-1 mRNA was determined by PCR on cDNA obtained after specific reverse transcription. The PCR products were evaluated by densitometric analysis of the expected $189 \mathrm{bp}$ band on gel electrophoresis and the results are expressed in arbitrary optical density (OD) units. mRNA: messenger ribonucleic acid; PCR: polymerase chain reaction; cDNA: complementary deoxyribonucleic acid. For further abbreviations see legends to table 1 and 3. 
of $\mathrm{rIFN}-\gamma$ induction (mFI=277 and 108, respectively). Surprisingly, ICAM-1 mRNA expression increased only after rIFN- $\gamma$ induction (OD 1.07 after culture and 0.59 before culture), suggesting that the enhanced ICAM-1 protein expression observed after culture in the absence of rIFN- $\gamma$ only resulted from post-transcriptional upregulation, whereas an additional transcriptional upregulation was observed in the presence of rIFN- $\gamma$.

As shown in figure 5, fusafungine inhibited both spontaneous and rIFN- $\gamma$-induced ICAM-1 protein expression on BAL cells in a concentration-dependent manner. ICAM-1 mRNA expression was slightly inhibited in rIFN- $\gamma$-treated cells only, whatever the concentration of fusafungine, indicating that fusafungine antagonizes the stimulatory effect of rIFN- $\gamma$ on ICAM- 1 protein expression and downregulates spontaneous expression in a concentration-dependent manner.

Dexamethasone inhibits basal but not IFN- $\gamma$-induced ICAM-1 expression on AM in vitro

Finally, the effects of fusafungine, a nonsteroidal antiinflammatory drug, on ICAM-1 expression in human BAL cells were compared with that of a glucocorticoid, dexamethasone. BAL cells were treated for $24 \mathrm{~h}$ with 0 , $0.1,1$ and $10 \mu \mathrm{g} \cdot \mathrm{mL}^{-1}$ of dexamethasone $\left(2.5 \times 10^{-4}\right.$ to $2.5 \times 10^{-2} \mathrm{M}$ ), in the presence and absence of rIFN- $\gamma$. Before culture, $18 \%$ of AMs were CD54-positive with an mFI of 47 , confirming the basal membrane expression of ICAM-1. ICAM-1 expression was markedly increased in the presence of rIFN- $\gamma$, as the percentage of CD54-positive cells reached $89 \%$ after $24 \mathrm{~h}$ of culture and as antigen density was high $(\mathrm{mFI}=320)$. ICAM-1 expression was also enhanced in the absence of rIFN- $\gamma$, as the percentage of CD54-positive cells reached $88 \%$; however, antigen density was lower $(\mathrm{mFI}=116)$. As observed in the experiments with fusafungine, ICAM-1 mRNA levels increased only after rIFN- $\gamma$ induction (OD after culture 1.01, OD before culture 0.54 ), whereas it fell after culture without $\mathrm{rIFN}-\gamma(\mathrm{OD}=0.15)$. This suggested that the enhanced ICAM-1-protein expression observed after culture without rIFN- $\gamma$ resulted only from post-transcriptional upregulation, whereas culture with rIFN- $\gamma$ led to an additional transcriptional upregulation.

Dexamethasone did not influence rIFN- $\gamma$-induced ICAM-1 expression on AMs (fig. 5), even at the highest concentration $\left(10 \mu \mathrm{g} \cdot \mathrm{mL}^{-1}\right)$. Only the intensity of ICAM-1 expression on the AM surface was slightly reduced. The OD of the $189 \mathrm{bp}$ ICAM-1 band following PCR on cDNA was reduced at $10 \mu \mathrm{g} \cdot \mathrm{mL}^{-1}$ only and correlated with neither the percentage of CD54-positive cells nor the mFI. In the absence of rIFN- $\gamma$, dexamethasone partially inhibited ICAM-1 expression on AMs in a concentration-dependent manner, as the percentage of positive cells fell to $56 \%$ at $10 \mu \mathrm{g} \cdot \mathrm{mL}^{-1}$, whereas the mFI remained steady whatever the dexamethasone concentration. Surprisingly, ICAM-1 mRNA levels were enhanced by culture without rIFN- $\gamma$ in the presence of $0.1-1 \mu \mathrm{g} \cdot \mathrm{mL}^{-1}$ dexamethasone, but not by $10 \mu \mathrm{g} \cdot \mathrm{mL}^{-1}$. These results indicate that high concentrations of dexa- methasone antagonize the stimulatory effect of rIFN- $\gamma$ on ICAM-1 mRNA expression on BAL cells without reducing ICAM-1 protein levels. In contrast, dexamethasone downregulated basal expression of ICAM-1 antigen on BAL cells without affecting mRNA levels. Note that dexamethasone had no effect on HLA-DR expression.

\section{Discussion}

ICAM-1 expression on alveolar macrophages is increased in inflammatory lung diseases, and in vitro studies have indicated that ICAM-1 expression is regulated by rIFN- $\gamma$ and IL-1 produced by activated T-lymphocytes and macrophages [20]. It seems reasonable to assume that downregulation of ICAM-1 expression on AMs in airway tissues by drugs may constitute a therapeutic mechanism in the lung inflammatory process. Most previous studies of ICAM-1 regulation on monocytes/ macrophages have involved rat thymic macrophages [9], human blood monocytes [11], monocytic cell lines [10], or macrophage cell lines [21]. In the present study, we compared the effects of fusafungine and dexamethasone on ICAM-1 expression in human AMs freshly recovered from 14 BAL samples.

Treatment of AMs with rIFN- $\gamma$ for $24 \mathrm{~h}$ induced a significant increase in ICAM-1 expression, mainly at the transcriptional level. Culture without rIFN- $\gamma$ also resulted in a marked increase in the percentage of AMs expressing ICAM-1 protein, but at a lower intensity. Here ICAM-1 upregulation appeared to occur at a post-transcriptional level and might have involved activated migration of the intracytoplasmic protein to the cell membrane. Our results indicate that $\mathrm{rIFN}-\gamma$ is a potent inducer of ICAM-1 expression in AMs, in contrast to lipopolysaccharide (LPS) (data not shown).

As regards the mechanism of ICAM-1 downregulation in vitro, fusafungine may act at the transcriptional or post-transcriptional level, or inhibit protein migration to the cell surface. Fusafungine $\left(>8 \mu \mathrm{g} \cdot \mathrm{mL}^{-1}\right)$ inhibited the stimulatory effect of rIFN- $\gamma$ on ICAM- 1 mRNA expression in a concentration-dependent manner. However, GAPDH mRNA levels also fell as the fusafungine concentration increased, meaning that we could not quantify ICAM-1 mRNA relative to GAPDH mRNA. Fusafungine also downregulated $\beta$-actin mRNA (data not shown). Since the downregulation of GAPDH mRNA by fusafungine was 2.2 times weaker than that of ICAM-1 mRNA at a given concentration, fusafungine acts more specifically on ICAM-1 transcription gene than on others. Fusafungine $\left(>2 \mu \mathrm{g} \cdot \mathrm{mL}^{-1}\right)$ inhibited rIFN- $\gamma$-induced ICAM1 -antigen expression in a concentration-depen-dent manner, reaching a total inhibition at $16 \mu \mathrm{g} \cdot \mathrm{mL}^{-1}$. ICAM-1 antigen density fell in parallel. However, the expression of other membrane antigens, such as HLA-DR, was not altered. Altogether, these data strongly suggest that the marked inhibitory effect of low concentrations of fusafungine on rIFN- $\gamma$-induced ICAM- 1 expression by AMs acts at a post-transcriptional level, whereas high concentrations of the drug act on the transcription of numerous genes, although more markedly on ICAM-1 gene. 
The mechanism by which fusafungine regulates ICAM-1 expression may be related, at least in part, to its ionophoric properties, as the drug acts as a mobile cation carrier at concentrations higher than $0.01 \mu \mathrm{g} \cdot \mathrm{mL}^{-1}$. Fusafungine is a mixture of seven enniatins, i.e. cyclohexadepsipeptides with ionophoric properties, that modify membrane permeability to potassium. Because of their high solubility in polar media, enniatins enter the inner cell compartment, thus directly influencing basic vital processes $[22,23]$. Moreover, their ability to fix and transport through cell membranes not only $\mathrm{K}^{+}$but also $\mathrm{Na}^{+}$and divalent cations, such as $\mathrm{Mg}^{2+}$ and $\mathrm{Ca}^{2+}$, might be responsible for alterations of the vital functions, such as the overall transcription process.

Why the inhibitory effect of fusafungine at high concentrations persisted after drug removal may be explained by the fact that inhibition of ICAM-1 mRNA synthesis by high concentrations of the drug is only overcome after at least $24 \mathrm{~h}$ of culture in the absence of the drug. Alternatively, fusafungine may persist inside the cells after drug removal. In contrast, at low concentrations fusafungine did not inhibit rIFN- $\gamma$-mediated activation that persisted following removal of the cytokine.

ICAM-1 appears to play an important role in the inflammatory response during lung allograft rejection. ICAM-1 downregulation may explain the effects of treatments for acute rejection. Indeed, inhibition of lymphocytic and neutrophilic cell infiltration of perivascular spaces increases with the intensity of immunosuppressive treatment in transbronchial lung biopsies during acute lung rejection [24]. Dexamethasone rapidly acts on pulmonary inflammation characterized by APC and T-cell activation, T-cell proliferation and cytotoxic functions, suggesting that it might act on cellular adhesion mechanisms. Our findings provide evidence that the anti-inflammatory glucocorticoid dexamethasone, unlike fusafungine, may not antagonize rIFN- $\gamma$-induced ICAM-1 protein expression, despite a partial inhibitory effect on ICAM-1 gene transcription at a high concentration. In culture, dexamethasone appeared to partially inhibit spontaneous ICAM-1-protein expression but not ICAM-1-gene transcription.

These results are in keeping with reports that $10^{-5} \mathrm{M}$ dexamethasone does not abrogate TNF-induced expression of ICAM-1 on human dermal microvascular endothelial cells (HDMEC), as shown by means of immunocytochemistry [25]. More recently, the same authors tested four steroids for their effects on HDMEC treated for 24 $\mathrm{h}$ with TNF and/or IL-1 $\beta$, which appear to be strong inducers of ICAM-1 expression. None of the steroids, which included dexamethasone, influenced cytokineinduced ICAM-1 expression, strongly suggesting that the anti-inflammatory effects of steroids are not related to ICAM-1 modulation, at least in HDMEC [26]. In contrast, using immunoperoxidase-based techniques, other authors found that ICAM-1 expression was upregulated on freshly isolated rat thymic macrophages after culture with rIFN- $\gamma$, IL- 1 and TNF- $\gamma$, and downregulated by dexamethasone [9]. Again, dexamethasone inhibits both constitutive and IL-3- or GM-CSF-induced expression of the ICAM-1 antigen on purified normal human blood monocytes [11]. It has also been reported that dexamethasone can inhibit ICAM-1 transcription directly both in undifferentiated and differentiated (macrophage-like) cells of the human monocytic line U937, as shown by means of flow cytometry and northern blotting [10]. In our model, dexamethasone appeared to downregulate spontaneous ICAM-1 protein expression on human AM in culture and to antagonize the stimulatory effect of rIFN- $\gamma$ on ICAM- 1 transcription. Fusafungine antagonized the stimulatory effect of rIFN- $\gamma$ on ICAM- 1 protein expression and downregulated its spontaneous expression, but did not appear to act directly at the transcriptional level.

Drugs like fusafungine that locally inhibit ICAM-1 expression by AMs may have therapeutic potential in inflammatory diseases of the respiratory tract. The observation that dexamethasone did not inhibit rIFN- $\gamma-$ induced ICAM-1 expression in our human AM model strongly suggests that anti-inflammatory drugs act on different cellular and molecular targets and should, thus, be studied in various in vitro systems.

\section{References}

1. Lohmann-Matthes ML, Steinmüller C, Franke-Ullmann G. Pulmonary macrophages. Eur Respir J 1994; 7: 16781689.

2. Simmons D, Makgoba MW, Seed B. ICAM, an adhesion ligand of LFA-1, is homologous to the neural cell adhesion molecule, NCAM. Nature 1988; 331: 624-627.

3. Staunton DE, Dustin ML, Springer TA. Functional cloning of ICAM-2, a cell adhesion ligand for LFA-1 homologous to ICAM-1. Nature 1989; 339: 61-64.

4. Fawcett J, Holness CLL, Needham LA, et al. Molecular cloning of ICAM-3, a third ligand for LFA-1, constitutively expressed on resting leukocytes. Nature 1992; 360: $481-484$.

5. Vives J. CD50 is the signal transducer ICAM. Immunol 1994; 2/3: 93-96.

6. de Fougerolles AR, Springer TA. Intercellular adhesion molecule 3, a third adhesion counter-receptor for lymphocyte function-associated molecule-1 on resting lymphocytes. J Exp Med 1992; 175: 185-190.

7. Mentzer SJ, Faller DV, Burakoff SJ. Interferon-gamma induction of LFA-1-mediated homotypic adhesion of human monocytes. J Immunol 1986; 137: 108-113.

8. Dustin ML, Rothlein R, Bhan AK, Dinarello CA, Springer TA. Induction by IL-2 and interferon-gamma: tissue distribution, biochemistry, and function of a natural adherence molecule (ICAM-1). J Immunol 1986; 137: 245-254.

9. Colic M, Drabek D. Expression and function of intercellular adhesion molecule-1 (ICAM-1) on rat thymic macrophages in culture. Immunol Lett 1991; 28: 251-258.

10. van de Stolpe A, Caldenhoven E, Raaijmakers JAM, van der Saag PT, Koenderman L. Glucocorticoid-mediated repression of intercellular adhesion molecule-1 expression in human monocytic and bronchial epithelial cell lines. Am J Respir Cell Mol Biol 1993; 8: 340-347.

11. Sadeghi R, Feldman M, Hawrylowicz C. Upregulation of HLA class II, but not intercellular adhesion molecule 1 (ICAM-1) by granulocyte-macrophage colony stimulating factor (GM-CSF) or interleukin-3 (IL-3) in synergy with dexamethasone. Eur Cytokine Netw 1992; 3: 373-380. 
12. Valent $\mathrm{P}$, Bevec $\mathrm{D}$, Maurer $\mathrm{D}$, et al. Interleukin-4 promotes expression of mast cell ICAM-1 antigen. Proc Natl Acad Sci USA 1991; 88: 3339-3342.

13. Striz I, Wang YM, Kalaycioglu O, Costabel U. Expression of alveolar macrophage adhesion molecules in pulmonary sarcoidosis. Chest 1992; 102: 882-886.

14. German-Fattal M, German A. Evaluation in vitro de l'activité anti-microbienne de la fusafungine. Ann Pharm Franç 1990; 48: 295-305.

15. Karam-Sarkis D, German-Fattal M, Bourlioux P. Effect of fusafungine on adherence of Haemophilus influenzae type $\mathrm{b}$ to human epithelial cells in vitro. Biomed Pharmacother 1991; 45: 301-306.

16. White RR, Mattenberger L, Giessinger N. Activité antiinflammatoire de la fusafungine: rôle des macrophages. Mal Medicam/Drugs Dis 1987; 3 (Suppl. 1): 57-62.

17. Labbe D. Activité thérapeutique de Locabiotal Pressurisé dans l'inflammation oropharyngée. Cah ORL 1988; 23 (Suppl. 4): 35-40.

18. Frachon I, Fattal-German M, Magnan A, et al. Emergence of inflammatory alveolar macrophages during rejection or infection after lung transplantation. Transplantation 1994; 57: 1621-1628.

19. Guyon T, Levasseur P, Truffault F, Cottin C, Gaud C, Berrih-Aknin S. Regulation of acetylcholine receptor $\alpha$ subunit variants in human myasthenia gravis. J Clin Invest 1994; 94: 16-24.
20. Andersen CB, Blaehr H, Ladefoged S, Larsen S. Expression of the intercellular adhesion molecule-1 (ICAM-1) in human renal allografts and cultured human tubular cells. Nephrol Dial Transplant 1992; 7: 147-154.

21. Aiello FB, Gusella L, Longo DL, et al. Inducible accessory function of a macrophage cell line. Immunopharmacol Immunotoxicol 1993; 15: 327-354.

22. Steinrauf LK. Beauvericin and the other enniatins. In: Sigel H, ed. Metal ions in biological systems. New York and Basel, Marcel Dekker, 1985; 19: pp. 139-171.

23. Ivanov VT, Evstratov AV, Sumkaya LV, et al. Sandwich complexes as a functional form of the enniatin ionophores. FEBS Lett 1973; 36: 65-71.

24. Clelland CA, Higenbottam TW, Stewart S, Scott JP, Wallwork J. The histological changes in transbronchial biopsy after treatment of acute lung rejection in heartlung transplants. J Pathol 1990; 161: 105-112.

25. Detmar M, Tenorio S, Hettmannsperger U, Ruszczak Z, Orfanos CE. Cytokine regulation of proliferation and ICAM-1 expression of human dermal microvascular endothelial cells in vitro. J Invest Dermatol 1992; 98: 147-153.

26. Hettmannsperger U, Tenorio S, Orfanos CE, Detmar M. Corticosteroids induce proliferation but do not influence TNF- or IL-1 $\beta$-induced ICAM-1 expression of human dermal microvascular endothelial cells in vitro. Arch Dermatol Res 1993; 6: 347-351. 